\title{
Melibea Lies
}

\author{
Connie L. Scarborough \\ Texas Tech University
}

\section{ABSTRACT}

A close rereading of the Tragicomedia de Calisto y Melibea reveals a singularly striking element of Melibea's personality-she is a habitual liar. She lies to Calisto, she lies to Celestina, she lies to her mother, she lies to her maid Lucrecia, she lies to her father, and most decisively, she lies to herself. While we might label the latter a mere case of self-deception or self-justification, her consistent proclivity to lie is at the center of her personality. Melibea exercises free will throughout the work. She decides to lie, to stray from the paths of truth, common sense, and realistic consideration of the consequences of her decisions. This fundamental trait of her personality contributes to the tragedia embedded in the hybrid title of the Tragicomedia.

KeYwords: Melibea, lies, self-deception, courtly love, sexual desire

\section{Melibea miente}

\section{RESUMEN}

Una lectura detallada de la Tragicomedia de Calisto y Melibea pone de manifiesto una característica única y notable de la personalidad de Melibea: es una mentirosa empedernida. Miente a Calisto, miente a Celestina, miente a su madre, miente a su criada Lucrecia, miente a su padre y, de forma más decisiva, se miente a sí misma. Aunque se puede llamar este último caso un simple ejercicio de autodecepción o de auto-justificación, la propensión constante a mentir constituye la esencia de su personalidad. Melibea actúa guiada por su libre albedrío a lo largo de la obra. Decide mentir, desviarse del camino de la verdad, del sentido común y la consideración de las consecuencias de sus decisiones. Este rasgo fundamental de su personalidad contribuye a la tragedia, como aparece en el título híbrido de la Tragicomedia.

Palabras ClaVE: Melibea, mentiras, auto-decepción, amor cortés, deseo sexual

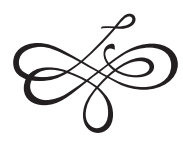


Melibea, hábil para la acción, es también hábil en el disimulo, en decir lo que no piensa para provocar la respuesta que busca, en salir de un aprieto gracias a una rápida mentira. (María Rosa Lida de Malkiel, 1962: 415)

I begin with the premise that Melibea's protestations throughout the Tragicomedia de Calisto y Melibea are overblown, overly dramatic, and in a sense reflect the idea of "she doth protest too much.» However, this seems to be a somewhat superficial assessment since a close rereading of the Tragicomedia reveals a more salient element of her personality aptly noted in the above quote from María Rosa Lida de Malkiel: Melibea lies. She lies to Calisto, she lies to Celestina, she lies to her mother, she lies to her maid Lucrecia, she lies to her father, and most decisively, she lies to herself. While we might label the latter a mere case of self-deception or self-justification, her consistent proclivity to lie is at the center of her personality, as I intend to show.

The critical evaluation of Melibea's role(s) and character in the Tragicomedia falls roughly into two camps. First, those who attribute Melibea's acquiescence to Calisto to be the result of a philocaptio spell that Celestina casts on the yarn she takes to Melibea's home on the pretense of selling it. As Yolanda Iglesias has noted, the father of this theory is Peter Russell. ${ }^{1}$ Other highly respected critics followed Russell's lead, adding other elements such as the influence of the devil on other characters in the work and the central role that magic plays in determining their actions. ${ }^{2}$ Others see magic not as the unique factor guiding the plot, but rather emphasize Celestina's exceptional abilities to persuade and make others act on hidden desires. ${ }^{3}$ A second group of scholars emphasizes that Melibea's affair with Calisto and its tragic end result from conscious and freely-taken decisions on Melibea's part. Arguing for this point of view are Salvador de Madariaga, María Rosa Lida de Malkiel, Yolanda Iglesias, José Luis Canet Vallés, Laura Mier, and with some reservations, Joseph Snow. ${ }^{4}$ I agree with those critics who see Melibea's choices as products of her free will, but among the choices she makes is a penchant to lie, and to lie constantly. In an insightful article, "Melibea's Suicide: The Price of Self-Delusion,» Victoria Burrus makes a clear and convincing case regarding Melibea's tendency to lie to herself, the self-delusion of the arti-

1.- See especially footnote 2 on pages 57-58 of her article, "Rompiendo las cadenas,» for a summary of critical opinions that emphasize the presence of magic and the devil as influential in the plot and character development in the Tragicomedia.

2.- In particular the work of Alan Deyermond and Javier Herrero, for example.

3.- Examples are studies by Patricia Botta, José Antonio Maravall, and Otis Handy. See also my article "Celestina and the Power of Old Age."

4.- See, for example, Snow's article "La metamorfosis de Melibea en la Tragicomedia de Calisto y Melibea.» 
cle's title. She calls Melibea's speech and actions a "charade» (1994: 65) and describes her as "playing with fire» (1994: 66). I would like to build on Burrus's arguments and add to her enumeration of Melibea's acts of self-deception as well as her willingness to deceive or lie to almost every other character in the Tragicomedia.

I am certainly not the first to point out that, after Calisto's initial entreaty to her in Auto I- «En este veo, Melibea, la grandeza de Dios» $(226)^{5}$-Melibea lets Calisto ramble on using the rhetoric of a courtly lover. ${ }^{6}$ Melibea even asks questions which allow him to elaborate on his «secreto dolor," and she promises him a "galardón»- - that coveted reward for the sufferings and sacrifices the courtly lover endures for his lady's sake. Perhaps she makes this offer, not in sarcasm, as Dorothy Severin indicates, ${ }^{7}$ but rather, in a rare break from her usual mien; in fact she actually is telling the truth. For, as we know, the "galardón» or reward that she will eventually give to Calisto is her virginity even though, as we shall see, not as reward for any great sacrifices or service on Calisto's part but simply because she wants to have a sexual relationship with him. Immediately after promising the "galardón,» she appears to change course and verbally attacks Calisto in what amounts to fraudulent threats to cover up the simple truth of what she has just uttered. In her rebuttal, she openly states that Calisto's proposal is "ylícito" (Burrus 1994: 61), a clue that she knows exactly what the aforementioned "galardón" means. Others have discussed the incongruities of this opening scene, especially the abrupt change in Melibea's attitude toward Calisto. Laura Mier states that Melibea's questions «suponen una ruptura con el papel tradicional asignado a la dama por el amor cortés» and attributes her queries to «curiosidad» or «ironía peligrosamente juguetona» (2008: 232). While I agree that Melibea is indeed acting dangerously here, I don't believe it is an attempt at irony. Joseph Snow sees Melibea's eventual, violent rebuff of Calisto as what would be expected of "una casta virgin y 'guardada hija'» for whom Calisto's advances set off an alarm that leads her to nervously send him on his way (2017: 154-55). She is doing what is expected of a virgin, the only daughter of a noble family, but I contend that it is mere show, a display of feigned innocence. On this point, I agree with Lida de Malkiel who contends that Melibea's eventual rebuke of Calisto «evidentemente no es espontáneo pudor de virgen lo que la mueve a rechazar a Calisto en el huerto» (1962: 406).

5.- All quotes are from the edition of Perter E. Russell ( $2^{\mathrm{a}}$ edition), unless otherwise noted.

6.- Kristen Brooks comments on Melibea's reply to Calisto's first words: «...she opens her mouth and responds, '¿En qué, Calisto?'..., thus opening up a space for a flirtatious-if ambiguous-exchange between the soon-to-be lovers» (2000: 100).

7.- «Melibea parece hacer un uso sarcástico de uno de los elementos primordiales del amor cortés, el del galardón o prenda de amor que premia la devoción del amante» (ed. de Severin, 89). 
Even though she sends Calisto packing, Melibea will later admit that she was smitten with him from Auto I, or perhaps even before the action of the drama as we know it begins. ${ }^{8}$ Her threats, then, may be a veiled attempt to lie to herself about her true feelings as well as her willingness to act on those feelings. Burros contends that «In this first meeting she [Melibea] appears to want to toy with Calisto a bit, perhaps to see to what extent he was willing to play the role of the long-suffering but ever patient and adoring lover» (1994: 62). As we know, Calisto is to be neither long-suffering, despite his overblown protestations and complaints to Sempronio and Celestina, nor patient, but that truth is lost on Melibea who will pursue her own desires as single-mindedly as will Calisto. In fact, as Mier points out, Calisto, rather than following the path of service and devotion to the object of his affections, finds a more efficient means to his end "pagando para que alguien [Celestina] lo haga por él de una forma más rápida y eficaz-se trata de una professional, no lo perdamos de vista...» (2008: 233). Iglesias calls Calisto's decision to handsomely remunerate an alcahueta of bad repute to secure the favors of Melibea equivalent to contracting her to procure Melibea, as if she were another of the Celestina's prostitutes (2010: 61). While neither Iglesias nor I would label Melibea a prostitute, the fact that Calisto indirectly pays, visa-vis Celestina, for her favors is a simple truth that Melibea would never admit in her customary habit of self-deception. ${ }^{9}$ Although there is nothing in the Tragicomedia that indicates that Melibea is privy to the details of Calisto's payments to Celestina, as we shall see, she knows Celestina, knows her reputation, her "oficios» and, thus, most probably knows that she doesn't work for free.

The reader next encounters Melibea during the first interview in her home with Celestina in Auto IV. Much has been written about the decision of Alisa, Melibea's mother, to leave her daughter alone with the alcahueta when she is suddenly called away to visit her sick sister. As previously stated, the theory of the influence of Celestina's magic spell has been invoked by some critics to account for the mother's absence. ${ }^{10}$ Alisa admits that she knows Celestina and is aware of her reputation, but

\section{8.- On this fact, see Lida de Malkiel, La originalidad, p. 422.}

9.- Melibea does, however, reference Celestina's role in her downfall in her speech to her father in Auto XX: «descubrió su [Calisto's] passión a una astuta y sagaz muger, que llamavan Celestina. La qual, de su parte venida a mí, sacó mi secreto amor de mi pecho» (599).

10.- A good example is Russell who argues for «la ayuda diabólica que está recibiendo la vieja en este difícil momento de su empresa... es cuestión de hacer a la normalmente cauta e iracunda Alisa salir despreocupadamente de su casa, dejando que Celestina empiece sin estorbo la seducción de Melibea» (319). I, on the other hand, agree with Mier regarding the role of magic and Celestina's conjuring of the devil at the end of Auto III: «Si bien es innegable la importancia de magia en el texto y se debe considerar como un 'tema integral', pero no para explicar el comportamiento de Melibea, ya que no es necesario, sino más bien para entender la caracterización de Celestina.... Más aún, la propia Celestina no confía totalmente en la 
she is both an arrogant and negligent mother who believes that she has raised an untouchable young virgin who is impermeable to Celestina's wiles. As Iglesias points out, just as Melibea earlier should have summarily dismissed Calisto as soon as he opened his mouth, Alisa should have thrown Celestina out of her house or, at best, attended to her herself and then sent her packing without allowing any access to her precious daughter (2010: 62). Instead, Alisa leaves her daughter alone with Celestina to negotiate for some thread that Celestina pretends to have come to her house to sell. ${ }^{11}$ In Celestina's subsequent conversation with Melibea, the go-between first tries to win the young woman's sympathy by bemoaning the rigors of old age and lamenting her poverty. ${ }^{12}$ Melibea participates in the conversation but when it comes to the moment when she is preparing to pay Celestina for the thread and send her on her way, the alcahueta admits that she has come for another purpose. Melibea, like her mother, knows Celestina and knows her "professions» so we cannot attribute her continuing to talk to Celestina once she alludes to another motive as anything but interest, feigned or otherwise, in the old woman's true mission. ${ }^{13}$ In fact, Lida de Malkiel asserts that "aunque desde el comienzo de la entrevista [Melibea] ha calado la intención de la tercera, se obstina en mantener la conversación con ella» (1962: 420). Once Celestina admits that she has come on behalf of an "enfermo," Melibea seems to jump at the opportunity to make a display of Christian charity for the sufferer. But when Celestina reveals the identity of the one on whose request she has come, Melibea's reaction, at first reading, appears to be one of utter rejection. However, if we examine more closely her words, we see that her rebukes are essentially lies, and that she is more than aware of exactly what Celestina wants from her. She threatens Celestina but then immediately vows not to do her any harm because she does not want to make public Calisto's and, by extension, Celestina's audacity: «Por cierto, si no mirasse a mi honestidad, y por no publicar su osadía desse atrevido, yo te fiziera, malvada, que tu razón y vida acabaran en

efectividad de su conjuro y así lo manifiesta en el monólogo camino a casa de Melibea» (2008: 234). On this last point, see also, my article "Speaking of Celestina,» pp. 215-16.

11.- Alisa, herself, realizes that Celestina has come to her house to ask for something, rather than to offer merchandise for sale; when Lucrecia announces who has come to visit, Alisa remarks: «iUna buena pieça! ... Algo me verná a pedir» (317). Lida de Malkiel sees the mother's delegation of the negotiation of the thread in her daughter's hands as practical, a sign of confidence in her ability to act on her mother's behalf: «no en balde la madre delega en ella el manejo de la casa en su ausencia, y la joven lo asume como si estuviese habituada a ello» (1962: La originalidad, 411).

12.- See my article "Celestina and the Power of Old Age.»

13.- Ximena Gómez Goyzueta observes that Melibea knowing Celestina is a clue that she is not the innocent she pretends to be: «...ni siquiera debería ser posible que tuviera el mínimo contacto con una vieja como Celestina, tanto por el bajo rango social de la vieja, como por su peligrosidad para la honra de las mujeres» (2013: 37). 
un tiempo" (329). Everyone knows that Celestina is audacious and leads others into reckless behavior, so there is no danger at all if Melibea chose to throw her from the house or even attack her for insulting a young woman of her stature and breeding. ${ }^{14}$ Furthermore, Melibea knows that Calisto is bold since he had already approached her in public with words of love. Her threat is empty and, essentially, a lie. In fact, she owns up to her own lie just a few lines later when she rhetorically asks Celestina: «Piensas que no tengo sentidas tus pisadas y entendido tu dañado mensaje?» (329). But Melibea continues the conversation and even alludes to her meeting with Calisto in Auto I explaining, when Celestina has not asked for any explanation, that the only reason that she didn't denounce Calisto when he approached her was she didn't want his audacity to become public- «quise más dexarle por loco que publicar su grande atrevimiento" (330) - the same reasoning, and the same lie, that she had just used to explain to Celestina why she has chosen not to punish her impudence. She even gives Celestina a chance to offer an excuse for mentioning Calisto to her: «ंTienes desculpa alguna para satisfazer mi enojo y escusar tu yerro y osadía?» (331). On this point, Burrus alludes to Melibea's demand that Celestina offer her an excuse for her impertinence, stating "This seemingly incongruous behavior is meant to give Celestina the message that Melibea will continue to play the game...» (1994: 64). Celestina is thus able to present the feigned toothache of Calisto and request the prayer and Melibea's cordón, petitions with which Melibea will comply, but not without more lies. She first excuses herself from any guilt or responsibility- «Pero la mucha razón me relieva de culpa, la qual tu habla sospechosa causó» (337) —and then asks Celestina to return tomorrow for the prayer since she doesn't have time to write it before her mother returns. Of course, if her intentions were honest, it would make no difference if her mother saw her writing out the poem to Santa Apolonia since her daughter would simply have been exercising a work of Christian charity. ${ }^{15}$ Burrus labels Melibea's invitation for Celestina to return a "charade of being a virtuous and pious woman concerned only for the health of a poor suffering soul» (1994: 65). When she finally dismisses Celestina, however, it is not with a lie but with a non-too-veiled truth: «Más haré por tu doliente, si menester fuere, en pago de lo sufrido»

14.- On this point Iglesias asserts «Por muy inocente que quisiéramos pensar que es Melibea, sabe que Celestina es una alcahueta y el hecho de que venga a hablarle de un caballero enfermo es motivo suficiente para que interrumpa la conversación y la eche de su casa. Melibea, sin embargo, no lo hace porque lejos de ser una jovencita ingenua es una muchacha muy viva y con deseos de saber más sobre el asunto que la vieja tiene entre manos...» (2010: 67-68).

15.- Mier calls this wish to hide the prayer from her mother a lie: «Que Melibea mienta a su madre es síntoma de que sabe que lo que hace no es apropiado en la esfera pública» (2008: 237). 
(338). ${ }^{16}$ Auto IV ends with Melibea uttering yet another lie in the form of a self-deception when she bids farewell to Celestina saying "ni tu mensaje me ha traýdo provecho, ni de tu yda me puede venir daño» (340). ${ }^{17}$ She knows Celestina's true nature and has given in to the initial entreaties she has made on Calisto's behalf in the form of the prayer and the sash. The idea that her meeting with Celestina has been purely innocent and will bring her neither benefit nor harm is pure fantasy. In fact, Lucrecia, Melibea's maid, alludes to her mistress's willingness to cooperate with Celestina's mission and her request that she return tomorrow when her mother is not present: "¿Secretamente quiere que venga Celestina? ¡Fraude ay! ¡Más le querrá dar que lo dicho!» (337). ${ }^{18}$ Snow explains that Lucrecia was well aware of the "secreto amor» that Melibea harbors for Calisto (2017: 159), implying that Melibea is doing a very poor job of dissimulating her true desires. In other words, Lucrecia recognizes that Melibea is lying about her feelings for Calisto as well as acknowledging the fact that her mistress is actually a very bad liar.

Snow calculates that some twelve to thirteen days have passed until we again encounter Melibea at the beginning of Auto X (2017: 160). During this period of almost two weeks her efforts at dissimulation and self-deception have failed and she sends Lucrecia to Celestina's house to summon the alcahueta to her home. Lucrecia tells Celestina that her mistress «se siente muy fatigada de desmayos y dolor del coraçón» (436). In the monologue that opens Auto X, Melibea laments having rejected Calisto's initial entreaties. She has already fallen in love (lust?) with him, as Snow observes, "La realidad es que se sintió cautivada con la vista de Calisto ('aquel cavallero') en la primera escena, puesto que no hubo otro encuentro con él» (2017: 156). She fears that in the time that has passed since that first meeting Calisto may have fallen in love with another. ${ }^{19}$ On this point Burrus comments that Melibea «clearly sees that she has lost the upper hand in her strategy of showing haughty rage at the very suggestion of his love suit and pretending to believe that Calisto truly wanted no more than relief for a toothache» (1994: 69). Melibea comments that Lucrecia will be shocked to learn of her feelings for Calisto. ${ }^{20}$

16.- Lida de Malkiel cites this line as indicative of the fact that «Rojas no se propuso a pintar una 'incauta virgen' ni una 'virginal doncella' - una empobrecido esquema convencional—sino una figura llena de vida y turbiamente agitada por su pasión» (1962: 421).

17.- Salvador de Madariaga notes the duplicity in Melibea's parting words to Celestina: "La misma Melibea pone punto final a este episodio con una declaración inversa de lo que ronda por sus adentros: deseo y temor» (1972: 75).

18.- To this comment by Lucrecia, Severin, in her edition of La Celestina, adds the following footnote: "Lucrecia nota la complicidad de Melibea en la intriga» (170, fn 67).

19.- See my article, «Speaking of Celestina,» pp. 223-24.

20.- «i mi fiel criada Lucrecia! ¿Qué dirás de mí, qué pensarás de mi seso, quando me veas publicar lo que a ti jamás he quesido descobrir? ¡Cómo te espantarás del rompimiento de 
This is but another indication of Melibea's self-deception because, as we have seen, Lucrecia is well aware of her mistress's passions and the dangers they pose. Melibea's anguished soliloquy includes a prayer to God to help her conceal her passions and feign another cause for her suffering- « $\mathrm{O}$ soberano Dios! ... húmilmente suplico des a mi herido coraçón sofrimiento y paciencia, con que mi terrible passión pueda dissimular,... publicando ser otro mi dolor, que no el que me atormenta» (440). ${ }^{21}$ "In other words, she prays for the ability to be a good liar and a good actress» (Scarborough 2012: 224). ${ }^{22}$ On Melibea's soliloquy as she anxiously awaits the arrival of Celestina, José Luis Canet Vallés remarks: "Melibea... arde de deseos tanto o más ${ }^{23}$ que Calisto y utiliza los mismos rezos sacroprofanos y reproduce las mismas quejas al no poder gozar de su amado» (2000: 224).

When Celestina arrives, Melibea greets her, calling the go-between "sabia,» "honrrada,» and "bienvenida» (441). Her initial greeting amounts to an invitation for Celestina to continue her work on behalf of Calisto:

¿Qué te parece, cómo [ha quesido] mi dicha y la fortuna ha rodeado que yo tuviesse de tu saber necessidad, para que tan presto me hoviesses de pagar en la misma moneda el beneficio que por ti me fue demandado para esse gentilhombre que curavas con la virtud de mi cordón? (441)

Otis Handy's analysis of this passage is insightful and I quote him in full:

"Melibea's question is subtle, for it first states that Celestina must return the favor Melibea rendered in lending the 'cordón' to cure Calisto; later in their exchange Celestina will turn this charge against her, referring to Melibea's 'deuda.' Second, Melibea conveys to the go-between that the payment must be 'en la misma moneda,' i.e., she already leads the way to a frank discussion. Her

mi honestidad y vergüença que siempre como encerrada doncella acostumbré tener!» (440) On this passage, Lida de Malkiel comments: «se estremece ante la posibilidad de que la criada haya descubierto la verdadera causa de sus 'desmayos e dolor de coraçón'» (1962: 422).

21.- Note, too, that she clearly recognizes that her desires may be dangerous as she refers to her passion as «terrible.»

22.- Otis Handy draws a parallel with Calisto's blasphemous pronouncement in Auto I when Sempronio asks him if he is a Christian and Calisto replies "Yo melibeo soy y a Melibea adoro y en Melibea creo y a Melibea amo" (235). Commenting on Melibea's prayer in Auto X, Handy remarks: "The parallelism with the blasphemous Calisto is obvious... But where Calisto turned away from God, Melibea would seek to divert Him from an honest, Christian path» (1983: 18). Canet Vallés emphasizes the catechumenal formula of Calisto's reply to Sempornio in Auto I, almost as if it were an article of faith: "La respuesta de Calisto, contra los que esperaríamos en un catecismo, corrobora la disfunción que supuestamente ha producido la enfermedad del amor en su imaginativa» (2000: 216).

23.- Emphasis mine. 
comment makes possible a transference from curing a 'llaga' to the real goal, establishing a meeting with Calisto. Her 'llaga' will serve the same purpose as did the 'toothache' of Calisto.» (1983: 19). ${ }^{24}$

Thus, from the beginning of her conversation with Celestina in Auto X, it is clear that Melibea is experiencing the same pangs of desire as Calisto. Melibea clearly displays all the signs of love sickness, ${ }^{25}$ and Celestina artfully plays the role of physician to her, drawing out the details of her symptoms and promising her a cure. She cleverly mentions Calisto's name at every turn finally eliciting a frustrated response from Melibea. Here, in a particularly lucid moment, Melibea recognizes that Calisto may not be the gallant swain she pretends him to be when she admits that he has not performed any of the courtesies or sacrifices required of a true courtly lover. This realization is borne out when she questions Celestina's insistence: "Tantas vezes me nombrarás esse tu cavallero.... ¿De qué ha de quedar pagado? ¿Qué le devo a él? ¿Qué le soy a cargo? ¿Qué ha hecho por mí? ¿Qué necessario es él aquí para el propósito de mi mal?» (448). In this outburst, Melibea makes it perfectly clear that she knows that Calisto has not done anything noble or generous to woo her. ${ }^{26}$ Celestina, at last, directly tells Melibea that her suffering is called "amor dulce» (449) and that Calisto is the only cure. Melibea faints when Celestina names Calisto as the remedy for her suffering. ${ }^{27}$ Celestina immediately fears for her own life should the true nature of their conversation and its effect on Melibea become known. When she calls Lucrecia to help her to revive Melibea, the latter suddenly comes to, fearing, just as had Celestina, that the reason for her swoon become public. She orders Celestina: "no escandalizes la casa» (450). ${ }^{28}$ Melibea's primary concern is maintaining her façade of innocence, i.e., concealing her desires for Calisto and its physical effects on her. Despite her concern to retain her public posture as the "dama noble encerrada»—a façade she hopes to also feign for the benefit of her parents-her passions and willingness to act

24.- On this passage, see also Russell: «Melibea con su cordón había ayudado a Celestina a que ésta curase el supuesto dolor de muelas de Calisto; ahora la muchacha pide a la vieja un favor semejante» (p. 441, fn 10).

25.- Melibea describes all the physical symptoms she is suffering: «túrbame la cara, quítame el comer, no puedo dormir, ningún género de risa querría ver» (444).

26.- Mier states: «Melibea tampoco se engaña con la actitud de Calisto, sabe perfectamente que no ha hecho nada para conquistarla...» (2008: 237).

27.- On this point, Mier asserts that «El proceso ascendente que comenzó en el auto IV con la primera mención del nombre de Calisto alcanza aquí su punto culminante tras el desmayo de Melibea, que sólo es capaz de admitir 'públicamente' su amor tras perder temporalmente la conciencia...» (2008: 237).

28.- When Celestina continues to be solicitous, Melibea rebukes her with a curt: «Calla, no me fatigues» (450). 
on them are beyond doubt. Melibea's speedy recovery, too, leads us to question the veracity of the fainting spell. ${ }^{29}$ Was it simply an act, a dramatic gesture as much for herself as for Celestina? Her long explanation for her temporary loss of consciousness is unexpected from one who, only seconds before, had led Celestina to believe that she might be dead. ${ }^{30}$ After explaining that her swoon resulted from the loss of her "honestidad,» "empacho,» and "vergüença» (450), she praises Celestina's persistence and ends by telling her that «has sacado de mi pecho lo que jamás a ti ni a otro pensé descobrir» (451). The secrecy of Melibea's desires is questionable since the reader is aware that Lucrecia, at least, knows of Melibea's passions and certainly those of Calisto toward Melibea are common knowledge among Sempronio, Pármeno, Elicia, and Areúsa. It is highly unlikely that none of these latter characters suspected that Melibea might harbor similar desires for Calisto. ${ }^{31}$

After Melibea confesses to Celestina that she reciprocates Calisto's feelings, the go-between announces that she will arrange for her to meet and speak with him at the door of her home that very evening at midnight. Melibea immediately agrees to the meeting with what Lida de Malkiel calls «entrecortado ritmo de compliciadad» (1962: 424). Melibea then asks Celestina to tell Calisto to approach «muy paso» (453), or stealthy, an indication that the meeting is both secretive and potentially dangerous. She also makes it clear that she will do whatever Calisto wishes: «se dará concierto, según su voluntad» (453). Celestina then abruptly ends their conversation when she hears Melibea's mother approaching. Melibea immediately turns to Lucrecia and asks for her complicity in keeping her meeting secret, while also disavowing any responsibility for the actions she is about to take: «ya as vista cómo no ha sido más en mi mano. Cativóme el amor de aquel cavallero" (453). ${ }^{32}$ Lucrecia reveals that she has been aware all along of Melibea's feelings but that she had chosen to remain silent. Mier maintains that it is curious that Lucrecia has known about Melibea's desires (2008: 238) but, in fact, we know that the maid has intuited the situation from her asides during the first meeting between Melibea and

29.- On Melibea's speedy recovery, Madariaga remarks: «...toda dama que se respeta sabe siempre cuándo es llegado el momento de dar fin a un desmayo y Melibea es de buena familia» (1972: 79).

30.- Here I obviously disagree with Brooks who calls Melibea's swoon «a bodily response outside of her control» (2000: 101) and "an involuntary bodily revelation» (2000: 102). Mier, likewise, states that Melibea's loss of consciousness «delata la autenticidad de sus sentimientos" (2008: 237).

31.- We know also that after the murder of Celestina, and the subsequent public sentencing and execution of Sempronio and Pármeno, that the affair will be common knowledge.

32.- On her excuse to Lucrecia, Lida de Malkiel maintains: «el justificarse ante la criada, dando por toda excusa su incapacidad de dominarse» (1962: 424). 
Celestina in Auto $I V$ and, especially, when she is sent to fetch Celestina on her mistress's behalf as occurs at the end of Auto IX.33

When Melibea's mother Alisa enters and finds her daughter with Celestina, she questions the go-between's presence in her home to which Celestina replies that she has come to complete the sale of the thread she had used as an excuse to enter the house at the beginning of Auto IV. After Celestina leaves, Alisa, finally showing a bit of concern about Celestina, questions Melibea as to the purpose of the alcahueta's visit. Here we catch Melibea in a flagrant lie to her mother when she replies that Celestina had come to sell her «un poquito de solimán» (454). ${ }^{34}$ Ironically, Alisa believes her daughter's lie rather than Celestina's and openly states that she knew that Celestina had lied to her when she realized that her reappearance at Melibea's house would not be welcome: «Pensó que recibiría yo pena dello y mintióme» (454). Alisa then, finally, decides to play the role of protective parent, warning her daughter about Celestina's nefarious reputation and the suspicions her presence in their home could provoke: «Daña la fama; a tres vezes que entra en una casa, engendra sospecha» (454-55). Melibea's reply is both ambiguous and deceptive when she tells her mother that she will not entertain any more visits from Celestina and that she knows «de quién me tengo de guardar» (455). Lida de Malkiel sees Melibea's reply to her mother's warning "como desafío burlón a la autoridad materna, simule gratuitamente sorpresa e ingenuidad en su promesa de obediencia» (1962: 417). Lucrecia aptly sums up the situation when she remarks, in an aside, that Alisa's warning has come too late and has fallen on deaf ears. ${ }^{35}$

In Auto XII, when Calisto approaches Melibea's home at midnight, he first asks Pármeno to go to the door to see if Melibea has kept their appointment. Pármeno is fearful that he will be caught in the course of the late night rendezvous, but beyond his own cowardice he worries that if someone other than Calisto first appears at the door, Melibea will realize that the affair is known to others. Of course, as we have seen, all in the circle of Calisto and Celestina are aware of the nobles' desires, and Pármeno's comment rings ironic since so many are already involved in arranging the clandestine meeting. When Calisto approaches the door and speaks to Melibea, she begins the conversation with lies and deceptions. Mier uses the verb «impostar» (2008: 238) to describe Melibea's initial words of rejection when Calisto recognizes her voice through the closed

33.- Lucrecia specifically tells Celestina that she has come to retrieve Melibea's sash (a seemingly valid excuse) but she also says that her mistress had asked her to bring Celestina immediately to her house because her mistress is suffering and wants Celestina to visit her.

34.- On this lie see Francisco Ramírez Santacruz (2004: 68). Russell notes the contradictory nature of Melibea's and Celestina's lies since the two women did not have time to coordinate an excuse to explain Celestina's presence before Alisa arrives (454, fn 73).

35.- «iTarde acuerda nuestra ama!» (455) 
door and declares himself to be her "siervo» (476). Melibea tells Calisto that she has only agreed to this meeting in order to discourage him from any further contact with her: "Desvía estos vanos y locos pensamientos de ti, por que mi honrra y persona estén sin detrimento de mala sospecha seguras. A esto fue aquí mi venida, a dar concierto en tu despedida y mi reposo» (476). ${ }^{36}$ In response, Calisto becomes distraught, unleashing an emotional tirade of curses and regrets. He rails against his servants and, in particular, against Celestina since she had given him to believe that Melibea was susceptible to his entreaties. Ironically, given that Melibea has just lied to him, he concludes his complaints by doubting if truth itself even exists. ${ }^{37}$ However, she soon admits that she appeared to dissuade him only to test his resolve. ${ }^{38}$ At this news, "Calisto flies into another fit of rhetorical verbiage, now rejoicing in his good fortune. He thanks God for having worked the miracle of bringing Melibea to him, but then subsequently doubts that any of this meeting is real...» (Scarborough 2012: 225): "me estoy remirando si soy yo, Calisto, a quien tanto bien se le haze» (479). ${ }^{39}$ Melibea then admits that she has been pining away for Calisto for many days and that she has tried, in vain, to dissimulate her desires. In other words, she has been trying unsuccessfully to live a lie. She boldly tells Calisto that he may do with her as he pleases: "te suplico ordenes y dispongas de mi persona segund querrás» (480). However, as Burrus explains, this patent invitation to Calisto is made from behind locked doors: "It is important to note that this frank declaration of her physical desire is made from behind the safety of sturdy gates...» (1994: 71). Calisto, who had proclaimed himself a Melibean, not a Christian, in Auto I, now seeks divine intervention, praying that God send down fire to burn the doors that impede his physical access to Melibea. ${ }^{40}$ Melibea, again wanting to avoid scandal, persuades him not to break down the doors and pacifies him with an invitation to visit her the following night in her garden. She admits that she fears her fa-

36.- Russell uses the verb «fingir» to describe Melibea's initial lie to Calisto: «En este primer parlamento de Melibea, la muchacha, contraria a las esperanzas de Calisto, finge adoptar la postura de una mujer ofendida por infracciones de las leyes del amor cortés» (476, fn 32) (emphasis mine).

37.- On this point, see my article "Speaking of Celestina» (2012: especially p. 225).

38.- Lida de Malkiel observes that, at this juncture in the Tragicomedia, «reaparece la Melibea de los actos I y IV, amiga de poner a prueba al interlocutor diciéndole lo contrario de lo que de veras piensa...» (1962: 424).

39.- On Calisto's sometimes tenuous grasp on reality and his tendency to doubt whether what he experiences is a dream or reality, see my article "The Tragic/Comic Calisto: Obsessed and Insecure.»

40.- « $\bigcirc$ molesta y enojosas puertas! ¡Ruego a Dios que tal huego os abrase como a mí da guerra, que con la tercia parte seríades en un punto quemadas!» (480) 
ther will learn of her "yerro» (480) ${ }^{41}$ and Calisto again blasphemes in his response, denying that Melibea is committing an error and attributing her invitation as an answer to his prayers: «¿Por qué llamas yerro aquello que por los sanctos de Dios me fue concedido? Rezando oy ante el altar de la Madalena, me vino con tu mensaje alegre aquella solícita muger» (481). ${ }^{42}$ When a contingent of watchmen draw near, Calisto departs. But the noise awakens Melibea's parents and Melibea resorts again to her propensity to lie. When her father questions her about the commotion, she tells them that it is just Lucrecia who had gone to fetch her a drink of water. Lida de Malkiel points out that just as Melibea had previously lied to Calisto when they begin to speak at the doors of her home, as their meeting ends "vuelve a esgrimir la rápida mentira como defensa para desvanecer la sospecha de su padre» (1962: 417). ${ }^{43}$

The rest of Auto XII is essential to the overall plot of the Tragicomedia with the scenes of Sempronio and Pármeno demanding their share of the gifts Calisto had bestowed on Celestina, the murder of the alcahueta, and the swift capture and public execution of the servants. What is important for the present argument is that none of these horrendous acts dissuade or delay Calisto from pursuing his goal of meeting Melibea in the garden. In the following Auto XIII, when Calisto learns of the deaths, he bemoans the fact that his relationship to the deceased may besmirch his good name, but refuses to let any fear or loss of "honra» keep him from his date with Melibea: «Pues, por más mal y daño que me venga, no dexaré de complir el mandado de aquélla por quien todo esto se ha causado. Qué más me va en conseguir la ganancia de la gloria que espero, que en la pérdida de morir los que murieron» (508). Furthermore, as I have argued elsewhere, Calisto "quickly rationalizes that they all deserved to die-the servants who he had previously praised for their loyalty and bravery (although in reality they were neither), he now calls 'sobrados y esforçados' and Celestina, who he had previously called 'reyna y señora mía,'he now labels 'mala y falsa'» (2012: 226-27). ${ }^{44}$ Calisto's last comments in Auto XIII reveal his own proclivity for lies. In order to disassociate himself from the murder of Celestina and the execution of Sempronio and Pármeno, he decides

41.- Snow claims that Melibea «es perfectamente consciente de su 'gran yerro': su traición a sus padres, su crianza y la sociedad patriarcal...» (2017: 161)

42.- On Calisto's prayer in the Church of the Magdalen, see David Burton's article «Fallen, Unrepentant, and Unforgiven: Calisto at the Madalena.»

43.- On Melibea's consideration of her parents, Lida de Malkiel also observes: «En todo lo que va de la Tragicomedia, Melibea no se ha acordado de sus padres sino como de vallas para la satisfacción de su amor.... Es en este momento de la primera satisfacción clandestina cuando Melibea comienza a pensar en sus padres» (1962: 425).

44.- I conclude with the following observation: «Calisto, in this auto, re-examines his situation, delighted in the prospect of a sexual relationship with Melibea and determined not to let the death of Celestina or the public execution of his servants impede the pursuit of his own pleasure» (2012: 227). 
to pretend that he has been away and therefore knew nothing of what had transpired. Or, if that lie is not believed, he will feign madness "por mejor gozar deste sabroso deleyte de mis amores...» (509). ${ }^{45}$

As planned, the two lovers meet that evening in the garden of Melibea's home in Auto XIV. Melibea, in her initial greeting to Calisto,--Es tu sierva, es tu cativa, es la que más tu vida que la suya estima» (513) inverts the roles associated with amor cortés by labeling herself Calisto's servant rather than his liege lady. Ximena Gómez Goyzueta sees this inversion of roles as a sign that Melibea is declaring herself to be completely submissive to Calisto (2013: 38). This is a particularly insightful comment if we view Melibea's subsequent efforts to repel Calisto's physical advances as false. She first reproaches Calisto for groping her-"me fié en tus manos» (514) —and admonishes him not to take from her what can never be restored, i.e., her virginity. Calisto's reply is an exaggeration at best and a flagrant lie at worst. He claims he cannot stop himself because he has suffered his whole life for her. If we follow Snow's carefully established time line for the events of the Tragicomedia of five or six weeks since the lovers' encounter in Auto I until the time of their deaths, the time that Calisto has spent pining after Melibea actually represents a very short period in his life. He claims to have been «Nadando por este fuego de tu desseo toda mi vida» (515). ${ }^{46}$ Melibea makes a second attempt to still his roving hands- "no obren las manos quanto pueden» (515) - and, even though Calisto admits that his are «desvergonçadas manos» (515), he cannot resist touching her "gentil cuerpo y lindas y delicadas carnes» (515). ${ }^{47}$ Melibea sends Lucrecia away when she decides to have a sexual relationship with Calisto since she proclaims that she does not want any witnesses to her "yerro» (515). ${ }^{48}$ The fact that Melibea numerous times refers to her affair with Calisto as an «error» implies that she knows she is doing wrong but, even this consistent self-appraisal does not dissuade her from pursuing her passions.

Meanwhile, even though Lucrecia is not present, we can infer that she is not too far away, probably within listening distance since we are privy to Sosia's and Tristán's comments as they can overhear the lovers even from their post at the foot of the high walls of the garden. Tristán comments

45.- The excuse of madness is introduced in the Tragicomedia whereas in the Comedia Calisto only proposes the ruse of a "fingida absencia» (509).

46.- On Calisto's protestations, Burros observes: "Calisto has no intention of putting up with the protracted suffering of the lovers of literature» (1994: 72).

47.- Note that Calisto uses the word "carnes,» instead of "piel,» «cutis,» or «figura,» or some other less explicit term to refer to Melibea's body; «carnes," etymologically, clearly denotes the carnal nature of his intentions.

48.- On this detail, Mier remarks: «Melibea, conscientemente, expulsa a Lucrecia de la escena para que no haya 'testigos de su yerro' cuando la relación sexual va a tener lugar, magistralmente elidida de texto, por cierto” (2008: 238). 
that his master is «el más bienaventurado hombre que nasció» (516). They envy Calisto and fantasize about being in his place with a woman as lovely as Melibea (Ramírez Santacruz 2004: 68). Ramírez Santacruz reminds us that Sempronio, too, earlier, had envied Calisto and praised Melibea's beauty. Since the men in Calisto's circle all desire Melibea, this critic concludes that she has become "la mujer de todos'... al ser concebida como un objeto sexual en la mente de los criados» (2004: 68).

Melibea's speech of regret after having lost her virginity could be construed as comical if not for the gravity of the situation. When she bemoans having lost «el nombre y corona de virgen por tan breve deleyte» (516), the reader can assume that either Calisto is not a very good lover or that the consummation of their liaison did not live up to the romantic ideal she had envisioned for the experience. She imagines how her mother would react if she knew and realizes, too late, that her actions will dishonor her father's social standing and reputation. Snow questions whether Melibea is sincere in repenting what had just occurred because in her parting words to Calisto before he leaves the garden she implores him return, and often (2017: 162) ${ }^{49}$ : «no me niegues tu vista de día, passando por mi puerta. De noche donde tú ordenares, sea tu venida por este secreto lugar, a la mesma ora, por que siempre te espere apercebida del gozo con que quedo, esperando las venideras noches» (518). ${ }^{50}$ Snow concludes that, after this first sexual encounter, «En cuanto al estado mental de Melibea, la pasión sexual que le ha arrebatado su pudor de antaño no conoce límites y no admite controles» (2017: 162). ${ }^{51}$ Melibea will throw herself headlong into this love affair, completely oblivious to either its dangers or its sordidness: «So blind is Melibea to reality that she seems not to notice that her grand lover's response to the abject declaration of love with which she bids him farewell is a curt: 'Moços, poned el escala'» (Burrus 1994: 74).

Canet Vallés enumerates the ways in which Calisto, as well as Melibea, contravene moral and religious limits, concluding that "Calisto no solo comete el pecado de estupro, sino que además lo realiza con todos los agravantes, al realizar su acto de desfloración y posteriores contactos con Melibea en presencia de la criada Lucrecia; una vez conseguida su virginidad, se insiste en la repetición del mismo pecado..., y lo mismo ocurre con Melibea, la cual una vez ha probado el placer difícilmente se

49.- Burrus concurs with Snow and questions whether Melibea's lament is sincere or merely pro forma (1994:73).

50.- After her first sexual encounter with Calisto, Lida de Malkiel asserts that Melibea «solo atiende a sacar partido de su yerro para asegurarse la continuación de su amor» (1962: 426).

51.- Snow continues the explanation: «Se da cuenta de que no hay posibilidad de volver atrás, porque sabe que 'todo queda por' Calisto. La iniciativa ahora la toma ella para futuros encuentros e insiste en que de día pase Calisto por delante de la puerta de la casa a caballo y manda que venga a la misma hora en las venideras noches para perderse con el gozo que siente envuelta en sus abrazos» (2017: 162). 
puede apartar de él» (2000: 220). Also, as Burrus reminds us, Melibea deceives herself by projecting onto Calisto the manners and nobility of the perfect courtly lover, although he falls far short of meeting those ideals: "She desperately needs to believe this, for were he not the perfect lover, the sacrifice of her honor would become meaningless» (1994: 76). ${ }^{52}$

Melibea's commitment to a sexual relationship outside of marriage is driven home in Auto XVI in which the young woman overhears her parents discussing future marriage prospects for her. Pleberio, Melibea's father, is especially concerned about his daughter producing a legitimate heir as "nuestra hazienda... qual nuestro estado requiere» (544-45)..53 Pleberio seems to believe, without the shadow of doubt, his daughter's virginal innocence but reminds his wife that «No hay cosa con que mejor se conserve la limpia fama en las vírgenes, que con temprano casamiento" (545). Alisa, Melibea's mother, who we know is suspicious of Celestina's presence in her house and perhaps doubts the seemingly innocuous interaction of the go-between with her daughter, disavows any responsibility in arranging the marriage, placing it all in her husband's hands while insisting on Melibea's "casto bivir y honesta vida y humildad» (546). It is Lucrecia, the maid, who actually overhears the parents' conversation and invites Melibea to eavesdrop with her. ${ }^{54}$ This act on Lucrecia's part could be construed as a bit malicious since we will learn of her jealousy of her mistress when the two lovers meet again in Auto XIX. Just before she calls Melibea to listen with her, Lucrecia, in an aside, remarks that with Celestina's death, there is no one to "remake» Melibea's virginity so that she could make the honorable marriage her parents are speaking about..$^{55}$ As Melibea listens to her parents she tells Lucrecia that she has been enjoying Calisto's nocturnal visits for a month and claims that he visits her every night. Melibea is either exaggerating or lying (to herself) since, in a conversation with Areúsa, Calisto's servant, Sosia, reports that «en un mes no avemos ydo ocho vezes, y dicen los falsarios

52.- Burrus further comments: «Thus, while in the beginning the portrayal of Calisto as a parody of the courtly lover is humorous, once Melibea succumbs, her inability to see Calisto for what he is takes on a pathetic quality that approaches the tragic when she allows her self-delusion about the grandeur of their love to induce her to take her own life» (1994: 76; emphasis mine).

53.- On Pleberio's economic concerns vis-a-vis his daughter's future see Alan Deyermond's article «Pleberio's Lost Investment: The Worldly Perspective of Celestina.»

54.- Lida de Malkiel describes this scene as follows: «Con su técnica de enfoques simultáneos, el autor contrapone los viejos padres ilusos, que rumian lentamente su proyecto favorito de bien casar a la hija - 'vn mes ha que otra cosa no hazen ni en otra cosa entienden', comenta exasperada Melibea - a la joven, sumisa con su amante, rebelde con sus padres para defender el amor que es su razón de ser» (1962: 426).

55.- «Lo mejor Calisto lo lleva. No hay quien ponga virgos, que ya es muerta Celestina» (546). 
rebolvedores que cada noche» (560). ${ }^{56}$ Melibea completely (self-)justifies her devotion to Calisto and claims that he has sacrificed much to be with her: «Muertos por mí sus servidores, perdiéndose su hazienda, fingiendo absencia con todos los de la ciudad, todos los días encerrado en casa con esperança de verme a la noche»(550). ${ }^{57}$ As her parents continue to talk about their plans for their daughter's future, Melibea rejects the idea of marrying anyone, quoting the popular refrain «más vale ser buena amiga que mala casada» (547) and declaring «ni quiero marido, ni quiero padre ni parientes! Faltándome Calisto, me falte la vida, la qual, por que él de mí goze, me aplaze» (550)..$^{58}$ These pronouncements by Melibea provide a good deal of information about her emotional state and make it clear that she is only interested in sexual pleasure, outside of the bonds of matrimony. She affirms that marriage is not her objective with Calisto who she prizes as a lover, not as a potential husband. Just as Calisto at the end of Auto XIII had vowed to renounce his obligations, household, and social standing to concentrate all his energies on his passion for Melibea, in her monologue in Auto XVI, Melibea similarly abandons all other concerns but her affair with Calisto (Scarborough 2012: 229-30). When Pleberio suggests to his wife that they involve Melibea in the decision about a potential mate, Alisa's reaction is an exaggerated rebuttal, claiming that her "guardada hija» doesn't have the slightest idea about marriage or procreation. Her vehement protests reveal that Alisa may indeed suspect that her daughter, after her encounters with Celestina, is far from the spotless ingénue she portrays to her husband. Lida de Malkiel also sees in Melibea's exaggerated reaction to her mother's comments "resentimiento de adolescente, vivamente herida en el orgullo de la recién adquirida experiencia por la jactancia de la madre que la cree una niña ignorante» (1962: 428). This auto ends when Melibea can no longer abide listening to her parents and she sends Lucrecia to interrupt them with "algún fingido mensaje» (551)..$^{59}$ In other words, she directs her maid to

56.- Sosia's mention of «falsarios rebolvedores,» or false rumor mongers as defined by Russell (560), is further proof that Calisto's and Melibea's love affair and their nocturnal meetings (regardless of their frequency) are known to many.

57.- On Melibea's efforts to justify her unfailing dedication to her love affair with Calisto, see Mier (2008: 238-39). Burrus claims that Melibea sees these events as "heroic sacrifices that he has made for her sake, sacrifices that demand that she respond in kind with equally heroic gestures» (1994: 78)

58.- Madariaga analyzes Melibea's declaration as follows: «A los proyectos matrimoniales de sus padres, ella opone una razón absoluta, que es irrebatible — su amor a Calisto-, y un sinnúmero de razones relativas, todas malas y flojas de que echa mano para cubrir su error» (1972: 85).

59.- Javier Muñoz-Basols comments that Melibea sending Lucrecia to interrupt the parents' discussion marks the "complicidad que ya existe entre los dos personajes [Melibea and Lucrecia], pero además, simbolizando que Melibea ya no atiende bajo ningún concepto a la potestad familiar» (2003: 1994: 118). 
lie to her parents.$^{60}$ At this point, Melibea's parents (at least her father) are deceived about their daughter's sexual experience as Melibea clearly explains when she tells Lucrecia: «estoy enojada del concepto engañoso que tienen de mi ignorancia» (551). Melibea is deluded into believing that she is living a "grand amor,» in spite of the fact that Calisto's pursuit of sexual satisfaction is only thinly veiled in empty courtly rhetoric. All threeCalisto, Melibea, and Lucrecia-construct a trail of deceit, self-delusion, overwrought rationalizations, and outright falsehoods.

Even before the final meeting of the lovers in Auto XIX "the situation was rapidly becoming untenable» (Burrus 1994: 78). Burrus points out that during Areúsa's meeting with the ruffian Centurio in Auto XVIII, Centurio reveals that he and, by extension, all in the city are aware of Calisto's and Melibea's love affair, Calisto's association with the deaths of Celestina, Sempronio, and Pármeno, and Calisto's nocturnal comings and goings. ${ }^{61}$ Only Calisto, Melibea, and the latter's parents seem to ignore the reality of the situation and the fact that the lovers' conduct has become general knowledge in the city.

In Auto XIX, Melibea and Lucrecia are singing, while, unbeknownst to the women, Calisto and his servants listen at the foot of the garden walls. Russell observes that the song belongs to the tradition of the cantigas de amigo that express a woman's impatience while waiting for her lover to appear (577). The song is full of erotic imagery-picking flowers, animals "saltando," young goats eager for their mothers' teats-and even mentions Calisto and Melibea by name, a clue that the lovers' tryst is becoming part of local, oral tradition. ${ }^{62}$ The fact that Lucrecia sings the first part of the song by herself and only in the latter strophes does Melibea join in is noteworthy because we will come to find out that Lucrecia is also attracted to Calisto and, thus, sings solo the first part of the love song (Russell 2018: 578). As Snow observes, when Calisto makes his appearance, interrupting the women's song, the scene "está teñida de lujuria por parte de Melibea, que ensalza con palabras su deseo...» (2017: 162) ${ }^{63}$ She

60.- Burrus when discussing Melibea's parents in this auto claims that «they see what they wish to see..., carrying their confidence in her to the point of negligence. Melibea, rather than expressing shame or regret for her deflowered state, boldly asserts her love for Calisto as a positive good, indeed, as her sole reason for living...» (76).

61.- Centurio: «....al cabo estoy. Todo el negocio de sus amores sé, y los que por su causa ay muertos, y lo que os tocava a vosotras, por dónde va, y a qué hora, y con quiénes» (566).

62.- Severin notes that the last strophe is a part of a popular villancico. The last strophe of the song sung by Lucrecia and Melibea- "La media noche es passada, / y no viene. / Sabedme si ay otra amada / que lo detiene» (581)--is reminiscient of the lyric, "la media noche es pasada / y el que me pena no viene, / mi desdicha lo detiene» (2020: 324, fn 5). For a thorough analysis of the content and antecedents for the lyrics sung by Lucrecia and Melibea, see Lida de Malkiel 1962: 428-30, fn 12.

63.- Severin states that Lucrecia «se ve también influida por la sensualidad de la escena» (2020: 325, fn 9). 
speaks of the shade cast by the trees (even though it is after midnight) that will cover with darkness their "deleyte.»" ${ }^{64}$ At this point, Lucrecia's passions are aroused by the sexual tension in the air and, as she helps Calisto to remove his armor, she uses the occasion to embrace him (Russell 2018: 583). ${ }^{65}$ Melibea immediately berates her maid for trying to occupy her place and her pleasures: "Déxame gozar lo que es mío; no me ocupes mi plazer» (583). Even though Melibea here speaks openly and frankly to Lucrecia about her desires, she still makes a feigned show of resistance, rebuking Calisto's roaming hands and the mishandling of her clothing: «tus deshonestas manos me fatigan quando passan de la razón. Dexa estar mis ropas en su lugar...» (583). Burrus sees in the protests of Melibea an unwillingness to admit to herself that Calisto is not the perfect courtly lover about whom she has just sung and greeted with such a flowery and joyful welcome (1994: 79). Her protests are but another example of self-delusion and, in a sense, a lie, since all her actions up to this point indicate that she wants to have sex with Calisto. ${ }^{6}$ When Melibea pleads with him — "no me destroces ni maltrates como sueles» (583-84)—we can infer that Calisto has been a bit rough in his lovemaking but, nonetheless, Melibea continues to invite him back for more. Her final admonition to her lover- «Qué provecho te trae dañar mis vestiduras?» (584)—may indicate that any tears or stains on her clothes will be hard to explain to her mother, another indication that she is careful to conceal any evidence of her nighttime activities. Calisto's crude retort to Melibea's reproach has been commented on by almost all critics of the Tragicomedia. Suffice it here to say that the popular refrain- -el que quiere comer el ave, quita primero las plumas» (584) is, at once, shocking and revealing. This is lust, not devoted love, and Calisto, desirous and desired, cuts to the chase. As Burrus notes, this "dicho" in Calisto's mouth "reveals his love as mere carnal desire» which degrades both he and Melibea (1994: 79). When he utters this boorish refrain, it is patent that the two are living a lie if they continue to believe that their relationship is formal, noble, and courtly; nonetheless, the reader is certainly aware of the true nature of their relationship long before this point. ${ }^{67}$

64.- Upon entering the garden, Calisto, also, makes an erotic allusion when he speaks of "complir el desseo de entrambos» (581), indicating that they are both equally sexually aroused.

65.- Madariaga notes that Rojas introduces a new psychological wrinkle into the plot when Lucrecia makes advances toward Calisto, «presentándonos los efectos que tanto espectáculo amatorio producen en la ardiente Lucrecia» (1972: 88).

66.- Lida de Malkiel maintains that Melibea's protests should not be seen as hypocritical as some critics have asserted given the fact that she has been in a consensual sexual relationship with Calisto for a month, but rather demonstrate «la delicada comprensión con que el interpolador (Rojas o quien fuese) presentó a la protagonista, en su abandono íntimo, mostrándola hasta en él apasionada y casta, con el pudor inherente de su naturaleza» (1962: 430).

67.- Of Calisto's response, Russell states that «con este grosero dicho popular comenta Calisto de modo cómico pero brutal las toscas realidades sexuales que se ocultan tanto detrás 
In an aside, Lucrecia, who is listening to the couple making love, expresses jealousy ${ }^{68}$ and even speculates about forming a relationship with one of Calisto's servants. She then comments that they have made love three times: "A tres me parece que va la vencida» (585). ${ }^{69}$ Calisto is called away from his lover at the sound of shouts from his servants, indicating that they are under attack. When Calisto falls from the ladder going to their aid, Melibea's first thought upon seeing her lover's shattered body below is to suppress the urge to scream and awaken the household: "hundiré con alaridos la casa de mi padre» (588). Calisto's servants rush to carry his lifeless body away from the walls of Pleberio's house, in an effort to save their master's honor. As we have seen, Calisto's visits to Melibea's home had become common knowledge and, thus their actions, while well-intentioned, are actually in vain. In a similar way, Lucrecia's immediate concern is to take Melibea away from «tan sospechoso lugar» (589), telling her that she must be just as strong in suffering the pain of her loss as she was bold and daring in the pursuit of pleasure- - Ten esfuerço para sofrir la pena, pues toviste osadía para el plazer» (589). But Melibea will be unable to heed Lucrecia's counsel and declares that she can no longer live without the pleasure she has known with Calisto. ${ }^{70}$ On Melibea's decision to not live without Calisto, Snow observes: "Tan profunda es la compenetración psíquica y sensual que comparten después de un mes Melibea y Calisto que para ella solo hay una decisión posible» (2017: 162). While I agree with Snow's evaluation, I also feel that Melibea, at this point, realizes that she has run out of lies. Her lover is dead, their love affair is far from secret, Calisto's involvement with Celestina and the execution of his servants for her murder is public knowledge, her parents have been either negligent or self-delusional up to now, she has lost her virginity, Celestina-the only one who could have remedied her non-virginal condition - is dead; and, as a dishonored woman, she will not be able to make a respectable marriage

del amor cortés como de la efusión de pasión romántica que el lector acaba de presenciar» (2018: 584, fn 46).

68.- Lucrecia: «iQue me esté yo deshaziendo de dentera, y ella esquivándose por que la rueguen!» (584)

69.- Russell notes that this phrase is somewhat ambiguous. He admits the usual interpretation that the lovers have had sex three times while Lucrecia and Calisto's servants are listening, but also points out the association with the saying "La tercera, buena y valedera» that means either that with the third shot, one finally hits a target or, in fighting, after an opponent is wrestled to the ground a third time, a winner is declared. Thus another possible meaning may be that it has taken three times for the lovers to get it right (2018: 585, fn49). Too, it is impossible not to see the humor in Lucrecia's aside since it begins with «Ya me duele a mí la cabeça de eschuchar» (584), indicating that having to listen to orgasmic pleasure while sitting on the sideline has, literally, given her a headache!

70.- Melibea: «No es tiempo de yo vivir. ¿Cómo no gozé más del gozo? ¿Cómo tuve en tan poco la gloria que entre mis manos tove?» (589). 
(and Melibea has rejected in principle an arranged or potentially profitable marriage as purposed by her parents). All this adds up to the inevitable and tragic ending to the Tragicomedia. ${ }^{11}$ Auto XIX ends with Lucrecia proposing a lie to disguise Melibea's distress: «fingiremos otro mal, pues éste no es para se poder encobrir» (590). ${ }^{72}$

Auto XX begins with Lucrecia summoning Pleberio to Melibea's room. The maid claims to be unaware of the reason for her mistress's agony but tells him that the situation is dire. Lucrecia, again, lies for Melibea's sake since she knows full well the cause of her affliction and the need to cover up the truth from her parents. In Pleberio's conversation with his daughter in her room, Muñoz-Basols emphasizes Pleberio's invocation of Melibea's mother as he tries to discern the reason for her distress: «Tu madre está sin seso en oýr tu mal. No pudo venir a verte, de turbada. Esfuerça tu fuerça, abiva tu coraçón, arréziate de manera que puedas tú comigo yr a visitar a ella» (592). In this passage, Muñoz-Basols affirms that «Pleberio intenta explotar semánticamente la imagen de la relación madre-hija para persuadir a Melibea...» (2003: 119). The absence of Melibea's mother at this crucial point in the action has been debated but it appears from her severe reaction to news of her daughter's anguish that she is unable, physically or mentally, to face up to the possibility of what Celestina's presence in her home has portended. ${ }^{73}$ As Pleberrio tries to animate his daughter, he suggests walking near the shore in the fresh air where her mother can join them: «alegrarte has con tu madre» (593). Her father's desperate pleas to revive Melibea's spirits again include an appeal to the mother-daughter relationship, one that the reader knows has been severely strained by Melibea's lies to her mother and Alisa's own failure to sufficiently protect her daughter. When Melibea suggests going to the top of a high tower to enjoy the view, Pleberio immediately agrees but she sends him for a musical instrument and instructs Lucrecia to tell him to wait for her at the foot of the tower, with the excuse that she wants to tell him something she had forgotten to tell her mother: "le quiero dezir una palabra que se me olvidó que fablasse a mi madre» (594). ${ }^{74}$ As if ech-

71.- Burrus comments that "Calisto's accidental death leaves Melibea with little alternative if she is to avoid the sense of chaos that would surely ensue from confrontation with reality" (1994: 80).

72.- Brooks comments on Lucrecia's suggestion to her mistress: «Lucrecia prompts Melibea to continue to perform the role of doncella encerrada, instructing her wailing mistress to go inside and feign some other malady in order to conceal the nature of her pain" (2000: 104).

73.- Muñoz-Basols states that «Alisa intuye, presiente, pero no acierta a comprender desde muy entrada la obra que aquello que teme le pueda ocurrir a su hija» (2003: 119-20). Russell posits a less assertive suggestion in the form of a question in a footnote: «¿Será que el lector debe entender que Alisa tiene mala conciencia al recordar fue ella quien dejó a Celestina sola con Melibea en el Acto IV?» (2018: 592, fn 7).

74.- Lida de Malkiel addresses the falsehoods that Melibea tells her father and her maid in order to be alone and carry out her plan of suicide: «para sacrificar la vida a su lealtad amoro- 
oing her father's invocation of the absent mother, Melibea also here mentions her mother; what at first appears to be a lie to her father-that she needs him to take a message to her mother-is actually the truth since, once Pleberio learns of the reason for his daughter's suicide, it falls to him to convey the tragic news to his wife. Muñoz-Basols, referring to Melibea's pretext of telling something to her mother, sees an additional truth in this statement: "Esta palabra [madre] no es más que toda la verdad que se reduce a la trasposición, el intercambio y la conversión en mercancía de la palabra madre, que Melibea ha manipulado bajo su conveniencia infectando su significado, estableciendo un línea antagónica entre la madre legítima Alisa y la mala putativa Celestina, causante de su trágico desenlace y depositando tal relación afectiva en el personaje de Celestina mediante el uso de la adopción discursiva, para concluir confesando su culpa y su deshonroso final...» (2003: 120-21). This critic supports his conclusion by citing the line in Melibea's monologue directed to her father, when referring to her dealings with Celestina, in which she admits "Descobrí a ella [a Celestina] lo que a mi querida madre encubría» (599).

Kristen Brooks calls Melibea's recitation to her father from atop the tower a "tragic performance»: "In her final speech and her suicide, Melibea both reveals to her father her prior abandonment of the role of doncella encerrada and dramatizes an even more radical abandonment of this role, seizing control over her own body and the 'truth' it speaks that she did not exercise when, as a doncella encerrada, she attempted to keep intact the boundaries of her self, or at least the appearance of being contained» (2000: 104). Melibea is in complete control of this, her final scene. Iglesias cites Melibea's monologue from atop of the tower as she awaits her father in which she freely admits- "Todo se ha hecho a mi voluntad» (595)—as confirming that she has always been in control, not only of her desires, but also of her errors (2010: 70). ${ }^{75}$ While this is clearly true, it is also worth noting that Melibea asserts that, after her father hears the reasons for her suicide, he will not blame her for choosing to end her life: "Oye, padre viejo, mis últimas palabras, y si, como yo espero, las recibes, no culparás mi yerro» (598). ${ }^{76}$

sa, para explicar con inusitada nobleza su conducta, Melibea se escuda en la falsía que... es habitual en ella. Más aún: de esa falsía habitual se vale Melibea para protegerse en los actos pequeños de la vida; en este último caso, por ejemplo, para conseguir su propósito inmediato de quedar sola en la torre» (1962: 418).

75.- On this point, I have elsewhere argued: «Melibea follows her own desires and instincts throughout the Tragicomedia, even to the point of choosing her own time and way to die...» (2012: 230).

76.- Lida de Malkiel notes the frankness with which Melibea confesses everything to her father, «respaldada en la seguridad de la muerte (y también en la comprensión de su padre), confiesa altivamente su yerro» (1962: 418). 
However, she begins her explanation with a patent exercise in self-delusion and falsehoods. She proclaims that the entire city is mourning the death of Calisto. Lida de Malkiel labels her exaggerated proclamations about all the church bells ringing out, people wailing in the streets, everyone dressed in mourning in grief for the death of Calisto as «alejados de la realidad.... Melibea evoca ante su padre una visión del duelo por Calisto, de sones lúgubres, de ropas de luto, de ruina y desconcierto, que primero abarca la ciudad y luego el mundo entero" (1977: 102). Melibea's descriptions of the reaction to Calisto's death are certainly not in keeping with reality; only in Melibea's version of him is he the pillar of society whose passing would cause such universal anguish. The reader knows Calisto to be an obsessed and sexually desirous young man, willing to enlist the aid of a former madam and pay her handsomely to secure the favors of the woman he has set his sights on; he feigns ignorance of his servants' dealings with Celestina when they murder her; and, he is pretending to be out of town (or even mad) to shirk any responsibility other than that of pursing an illicit love affair. ${ }^{77}$ In other words, Calisto, certainly, is not the gallant, noble, and courtly lover that Melibea presents to her father (Burrus 1994: 82). She proclaims him to be «el más acabado hombre que en gracia nasció...; el dechado de gentileza, de invenciones galanas, de atavíos y bordaduras, de habla, de andar, de cortesía, de virtud» (598-99). ${ }^{78}$ Once she desists from these flights of fancy about the deceased, Melibea summarizes the essence of her affair with Calisto. She reminds her father of Calisto's fine lineage and his honorable parents ${ }^{79}$ - a somewhat ironic statement as, from her description of him, it seems that he would have been a likely candidate for the marriage her parents were planning in $\mathrm{Au}$ to XVI. Melibea tells her father that Calisto was madly in love with her and enlisted the aid of Celestina so that «su desseo... y el mío hoviessen efeto» (599). It is noteworthy that she does not shy away from saying that she, too, was desirous of a physical relationship with Calisto. She then confesses having given Calisto access to her father's house and, after he had breached the walls of the garden, he had also invaded Melibea's body. She confesses: "Perdí mi virginidad» (600). ${ }^{80}$ She further tells him that the affair lasted a month and that last night Calisto had suffered a deadly fall from the ladder as he descended rapidly to investigate a dis-

77.- For a character study of Calisto see my article «The Tragic/Comic Calisto: Obsessed and Insecure.»

78.- Russell, speaking of Melibea's hyperbolic description of Calisto states: «la desequilibrada muchacha no vacila en ver a su seductor como ejemplo de virtud» (2018: 599, fn 33).

79.- Calisto's parents never appear in the Tragicomedia and this is the only mention of them in the work.

80.- On the confession to her father, Lida de Malkiel remarks that Melibea's «noble franqueza» stands in sharp contrast to "la conducta siempre mezquina de las mujeres en el teatro de Siglo de Oro...» (1962: 431). 
turbance in the street below where his servants were keeping watch. "Melibea tells her father that Calisto's death invites her own and she has no other choice but to join him in the grave. She even directly addresses the deceased Calisto begging him to forgive her for the delay in joining him in death...» (Scarborough 2012: 230-31). She then asks Pleberio to bury her beside Calisto. Melibea tasks her father with the gruesome duty of informing her mother about her suicide and the reasons that led her to take her life: "Salúdame a mi cara y amada madre; sepa de ti largamente la triste razón por que muero» (602). Alisa's absence at this, the most critical moment in Melibea's short life, serves to reinforce her negligence in performing the roles of support and comfort naturally associated with the mother figure..$^{81}$ Melibea then throws herself from the tower.

In the following Auto, as Pleberio mourns his loss; in a lengthy lament he recognizes that Melibea had chosen death, in an exercise of her own free will (Iglesias 2010: 71): «mi Melibea mató a sí misma de su voluntad, a mis ojos, con la gran fatiga de amor que la aquexava...» (613-14). Melibea admitted that she was ultimately responsible for the death of Calisto, ${ }^{82}$ who she labels one the city's finest citizens, even though he died in the most ignoble of circumstances. Calisto's death, near Pleberio's home is in and of itself highly suspicious and, despite the efforts of Tristán and Sosia to remove his body and thus spare him dishonor in death- "Llevemos el cuerpo de nuestro querido amo donde no padezca su honrra detrimento" (588), - we know that Calisto is already implicated in the death of Celestina at the hands of his servants..$^{83}$ The death of one of the bestknown members of this society, Celestina, was already associated with his household and, as we have seen, the love affair was known to others as well; in the text Calisto's new servants (Tristán and Sosia), Lucrecia, Elicia, Areúsa, and Centurio (who enlists Traso el Coxo and two companions to frighten Calisto's servants) all reference the affair. If all these representatives of the lower strata of the city are aware of the nobles' love affair, it is safe to assume that others were also in the know. Melibea's suicide will bring further dishonor on Pleberio's household since Melibea pleads to be buried beside Calisto. The emotional and economic ruin that Pleberio laments in Auto XXI would be combined with social ruin as well. Moreover, Melibea dies in mortal sin and would not have received a Christian burial — an additional blow to Pleberio's position as a noble in society. Lida de Malkiel notes that despite the harsh realities that Pleberio will face in the light of Calisto's death and Melibea's suicide, in

81.- Reminiscent of her sudden absence in Auto $I V$ when she leaves to visit her sick sister, giving Celestina an opportunity to be alone with Melibea.

82.- "De todo esto fuy yo la causa» (598).

83.- Burrus notes that "Melibea neglects to mention the complication of Calisto's loss of honor due to the execution of his servants for the murder of Celestina, although she was well aware of these circumstances» (1994: 82). 
his speech in Auto XXI, he does not allude specifically to the loss of honor nor lament the condemnation of Melibea's soul to hell (1977: 111). She states with regard to Pleberio's attitude: «Más notable todavía que en el joven Calisto, a quien ciegan egoísmo y pasión, es la ausencia del sentido de la honra en el anciano Pleberio, que en ello se opone a la tradición literaria y a la realidad coetánea...» (1977: 111).

Melibea's ultimate self-delusion lies in the fact that her suicide, rather than some grand, romantic gesture snatched from popular courtly literature, represents her failure to realize that she was not in a love relationship that «surpassed even those sung in poetry and immortalized in the sentimental romances... [and she chooses to die] rather than live with the disaster her love affair has wrought for all concerned» (Burrus 1994: 83). Canet Vallés, exploring the personality of Calisto in the Tragicomedia, states that «a lo largo de la obra iremos descubriendo que simplemente se trata una retórica falsa...» (2000: 223). The same accusation can be made of Melibea and perhaps an even harsher one, since not only does she engage in false rhetoric clothed in the robes of amor cortés, she lies outright. As Iglesias convincingly argues, Melibea, like all the characters in Rojas's work, "va creando su destino según sus resoluciones.... Sus personajes tienen voluntad de actuar y eso hace patente su libre albedrío» (2010: 71). In other words, Melibea chooses to lie and these lies contribute to her tragic end. She had numerous opportunities to avoid the final outcome of the work. Rojas is not a fatalist (Iglesias 2010: 71) and even though Pleberio, in his final lament, curses fortune, love, and worldly existence itself, none of these factors actually causes Melibea's death. Frank Casa sees Pleberio's speech as reflecting the father's misjudgments about the «natural order» of both love and fortune (1968: 29). Melibea is not, however, a victim of forces larger than herself against which Pleberio rages, but rather, literally, her own victim. ${ }^{84}$ The ultimate decision to end her life results from the consequences of her own willingness to lie, deceive herself and, the failure to listen to one's better angels (Iglesias 2010: 71).

From the standpoint of Rojas's created universe, the ending could be none other than tragic. A great part of the work's genius lies with characters who are constantly presented with options. They muse about their choices in monologue and dialogue with other characters, they rationalize their decisions, and they choose paths to follow using their free will. Every decision, every action sets a particular set of circumstances in motion. The different levels of society influence one another's thoughts and actions and, therefore, break any traditional bounds established for the separation of their worlds. The world of the Tragicomedia reflects a soci-

84.- Madariaga sees Melibea as the central character of the Tragicomedia: «ella es quien lleva la iniciativa de lo que sucede en cuanto la impaciencia de Calisto...; ella quien ama, ella quien con los ojos abiertos decide entregarse; ella quien regula la táctica siempre delicada de su rendición; ella al fin quien se impone el castigo...» (1972: 59). 
ety where divisions of social status are permeable, where nobles speak coarsely and servants and ruffians quote Petrarch, where virginal doncellas burn with sexual desire, and death, rather than an heroic end, results from clumsy accident and ignominious suicide. The choice to lie, to stray from the paths of truth, common sense, and realistic consideration of consequences constitute, in the end, the tragedia embedded in the hybrid title, the Tragicomedia de Calisto y Melibea. 


\section{Works Cited}

BotTA, Patricia (1994). «La magia en La Celestina.» Dicenda: Cuadernos de Filología Hispánica, 12, pp. 37-67.

Brooks, Kristen (2000). «Discovering Melibea: Celestina's Uncontainable doncella encerrada.» Celestinesca, 24, pp. 95-114.

Burrus, Victoria A. (1994). "Melibea's Suicide: The Price of Self-Delusion.» Journal of Hispanic Philology, 19, nos. 1-3, pp. 57-88.

BurTON, David (2003). «Fallen, Unrepentant, and Unforgiven: Calisto at the Madalena.» Celestinesca, 27, pp. 35-41.

Canet Vallés, José Luis (2000). "Hechicería versus libre albedrío en La Celestina.» El jardín de Melibea: Monasterio de San Juan, Burgos, 18 de abril-20 de junio de 2000, coord. Juan Carlos Elorza Guinea, Sociedad Estatal para la Conmemoración de los Centenarios de Felipe II y Carlos V, pp. 201-28.

CASA, Frank P. (1968). "Pleberio's Lament for Melibea.» Zeitschrift für Romanische Philologie, 84, 20-29.

Deyermond, Alan (1977). «Hilado-cordón-cadena: Symbolic Equivalence in La Celestina.» Celestinesca, 1-1, pp. 6-12.

- (1990). «Pleberio's Lost Investment: The Worldly Perspective of Celestina, Act 21.» Modern Language Notes, 105-2, pp. 169-79.

Gómez Goyzueta, Ximena (2013). «La Tragicomedia de Calisto y Melibea: amor e ironía en Melibea.» Medievalia, 45, pp. 34-40.

Handy, Otis (1983). "The Rhetorical and Psychological Defloration of Melibea.» Celestinesca, 7-1, pp. 17-27.

Herrero, Javier (1984). «Celestina's Craft: The Devil in the Skein.» Bulletin of Hispanic Studies, 61-3, pp. 343-51.

IGLESIAS, Yolanda (2010). «Rompiendo las cadenas: el libre albedrío en los personajes de La Celestina.» Celestinesca, 34, pp. 57-73.

Lida de Malkiel, María Rosa (1977). Dos obras maestras españolas: El libro de buen amor $y$ La Celestina, 4th ed., Buenos Aires, Editorial Universitaria de Buenos Aires.

- (1962). La originalidad artística de La Celestina, Buenos Aires, Editorial Universitaria de Buenos Aires.

Madariaga, Salvador de (1972). Mujeres españolas, Madrid, Espasa Calpe. Maravall, José Antonio (1976). El mundo social de La Celestina, Madrid, Gredos.

Mier, Laura (2008). «La conciencia de Melibea.» Celestinesca, 32, pp. 231-43. MuÑOZ-BASOLS, Javier (2003). «La funcionalidad de la adopción discursiva en La Celestina: de Melibea a Melilithbea.»Celestinesca, 27, pp. 107-24. 
Ramírez SantacruZ, Francisco (2004). "Individualismo a ultranza en $\mathrm{La}$ Celestina: Areúsa y Melibea.» Graffylia: Revista de la Facultad de Filosofía y Letras, 2-4, pp. 64-71.

RoJAS, Fernando de (2020). La Celestina, ed. Dorothy S. Severin, 30 ${ }^{\text {th }}$ ed., Madrid, Cátedra.

- (2018). La Celestina: Comedia o tragicomedia de Calisto y Melibea, ed. Peter E. Russell, $2^{\text {nd }}$ ed., Madrid, Clásicos Castalia.

Scarborough, Connie L. (2007). "Celestina: The Power of Old Age.» Old Age in the Middle Ages and the Renaissance: Interdisciplinary Approaches to a Neglected Topic, ed. Albrecht Classen, Berlin, Walter de Gruyter, pp. 343-56.

- (2012). «Speaking of Celestina: Soliloquy and Monologue in the Tragicomedia de Calisto y Melibea.» Celestinesca, 36, pp. 209-36.

- (2010). «The Tragic/Comic Calisto: Obsessed and Insecure.» Celestinesca, 34, pp. 179-200.

Snow, Joseph T. (2017). "La metamorfosis de Melibea en la Tragicomedia de Calisto y Melibea.» Celestinesca, 41, pp. 153-66. 